\title{
縮小インピーダンス法を用いた衝撃応答スペクトルの近似計算
}

\author{
福田 達輝 ${ }^{* 1}$ ，柳瀬 恵一*2，岩佐 貴史 ${ }^{* 3}$
}

\section{Approximate computing of shock response spectrum using reduced impedance method}

\author{
Tatsuki FUKUDA $^{* 1}$, Keiichi YANAGASE ${ }^{* 2}$ and Takashi IWASA ${ }^{* 3}$ \\ ${ }^{*} 1,{ }^{* 3}$ Department of Engineering, Tottori University \\ 4-101 Koyama-cho Minami, Tottori-shi, Tottori 680-8550, Japan \\ ${ }^{{ }^{2}}$ Japan Aerospace Exploration Agency \\ 2-1-1 Sengen, Tsukuba-shi, Ibaraki 305-8505, Japan
}

Received: 20 January 2021; Revised: 8 March 2021; Accepted: 31 March 2021

\begin{abstract}
This paper presents an approximate computing method of a shock response spectrum induced by a drop-weight shock test. The proposed method is based on a reduced impedance method, and computes the shock response spectrum by synthesizing the vibration characteristics of the spacecraft equipment and shock test device. A computational efficiency of the traditional reduced impedance method is significantly improved by proposing the method to only synthesize the dominated vibration characteristics of the substructures. The shock responses on the simplified model of the drop-weight shock test device are analyzed by the traditional reduced impedance method and the proposed method. Then, the shock response spectra given by both methods are compared. The result shows that the proposed method provides the shock response spectrum with accuracy of $\pm 6 \mathrm{~dB}$ for the traditional methods, and the computation cost is decreased by $1 / 60$. This study offers a practicable approach to estimate an approximate shock response spectrum before a drop-weight shock test.
\end{abstract}

Keywords : Shock response spectrum, Approximate computing, Reduced impedance method, Low computational cost, Drop-weight shock test

\section{1. 緒言}

ロケットからの衛星分離，太陽電池パドルやアンテナ等の展開では保持部分のひずみエネルギーが瞬時に解放 されるため大きな衝撃が発生する(Wang et al., 2017 および 雨川他，2019). そのため宇宙機，搭載機器はシステ ム組み立て前に衝撃而性を確認する必要がある．搭載機器の衝撃試験では，図 1 に示す落錘式衝撃試験のような 実環境とは異なる代替的手法がしばしば用いられる(Lee et al., 2012，および 畑村他，2015)。このような代替的手 法はシステム全機の試験よりも低いコストで実施できるものの衝撃源や衝撃伝搬経路が実物の宇宙機とは異なる ため, 衝撃応答スペクトルで規定される衝撃環境条件を満たすように試験を行うことが必要となる(宇宙航空研究 開発機構，2017).しかし，供試体に負荷する衝撃力を事前に精度よく予測し且つ調整できる衝撃試験装置は十分 に確立されているとは言えず，現状では供試体の質量ダミーを用いて事前に衝撃試験を何度も繰り返し供試体に 負荷する衝撃力を調整することとなる。この調整作業は一般に高い熟練度を必要とし，且つ多くの時間を費やす ことから試験コストを増大させる要因の一つとなっている。

No.21-00036 [DOI:10.1299/transjsme.21-00036], J-STAGE Advance Publication date : 8 April, 2021

${ }^{* 1}$ 学生員, 鳥取大学大学院 工学研究科（广 $680-8550$ 鳥取県鳥取市湖山町南 4-101）

*2 正員, 宇宙航空研究開発機構（テ305-8505 茨城県つくば市千現 2-1-1）

*3 正員, 鳥取大学大学院 工学研究科

E-mail of corresponding author: iwasa@tottori-u.ac.jp 


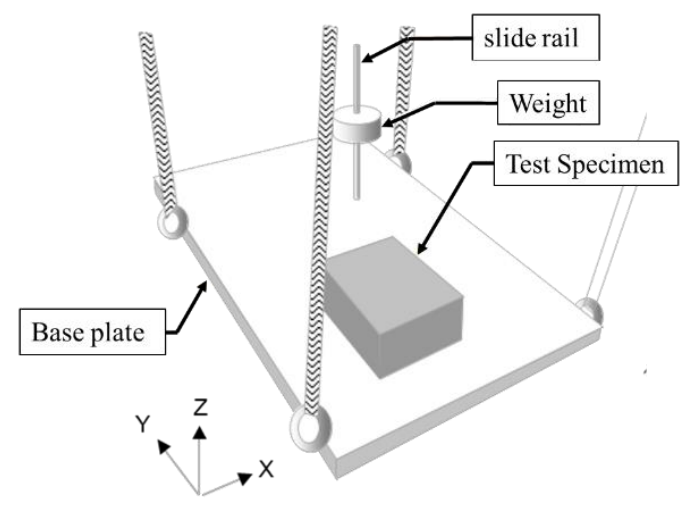

Fig. 1 A drop weight type shock tester. (JERG-2-130-HB001, 2017). A test specimen is installed on the base plate hanged with a cable. A shock load is applied to the base plate by a drop weight, and propagates to the test specimen.

このような状況を改善するため，筆者らは落錘式衝撃試験を対象に供試体に負荷する衝撃力を簡易的に予測で き, 且つ調整可能な衝撃試験装置の開発を行っている（柳瀬他，2019， Yanagase et al., 2020）。この衝撃試験装置 は搭載板と供試体との間に衝撃伝搬特性を調整するための機構を挿入するものであり，搭載板，調整機構，供試 体の 3 つの独立した構造体で構成されることから部分構造合成法（長松，大熊，1991）を用いた予測に適した装 置となっている，そこで筆者らは搭載板，調整機構，供試体のそれぞれの伝達関数をハンマリング試験で事前に 取得する場合を想定し, 伝達関数合成法を応用した衝撃応答スペクトルの予測法について検討した (柳瀬他, 2021). 本論文は, 搭載板, 調整機構, 供試体の構造数学モデルがある場合を想定し, 縮小インピーダンス法（長松他, 1982）を応用した予測法について検討する.

縮小インピーダンス法は搭載板, 調整機構, 供試体の特性行列（質量行列, 減衰行列, 剛性行列)を用いてイ ンピーダンスを求め, それらを合成することで結合系の応答を求める方法である. そのため, 各構造体の特性行 列だけを共有すれば結合後の衝撃応答を求めることができ，ハンマリング試験を行う必要がないといつた利点が ある.しかし，この手法は縮小インピーダンスを計算する過程で，周波数帯域が広くなるほど，周波数刻み幅 (分 解能）が小さくなるほど計算負荷が高くなるといった欠点がある. 本研究で対象とする衝撃応答スペクトルの上 限周波数は $5,000 \mathrm{~Hz}$ としていることから，衝撃応答スペクトルの計算で用いる加速度時刻歴波形の推奨サンプリ ング数は $50,000 \mathrm{~Hz}$ 以上となる(宇宙航空研究開発機構，2017). この時刻歴波形を求めるのに必要な周波数応答関 数はナイキスト周波数を考慮して $25,000 \mathrm{~Hz}$ 以上となり, このような広周波数範囲の応答を縮小インピーダンス法 で計算するには計算負荷を小さくすることが実用上重要となる.

そこで本論文では，搭載板，調整機構，供試体のそれぞれの縮小インピーダンスを主要な振動成分のみに着目 して計算することで従来の縮小インピーダンス法の計算負荷を著しく低減する方法を提案する. 提案する方法は 主要な振動成分のみに着目するため衝撃応答スペクトルの予測精度は劣化する。そこで, 従来の縮小インピーダ ンス法の結果に対してNASA の衝撃試験規格（NASA，2011）が定める土6 dB の試験公差範囲を目標值とした. そしてこの範囲において，2 種類のモデルを対象に提案手法による計算負荷の低減効果を検証する.

\section{2. 衝撃応答スペクトルの近似計算法の提案}

\section{$2 \cdot 1$ 縮小インピーダンス法を用いた衝撃応答スペクトルの計算法}

従来の縮小インピーダンス法（長松他，1982）を用いた衝撃応答スペクトルの計算方法を以下に示す．図 2 に 示すような 2 つ分系からなる構造物を解析対象とする. 分系 $\mathrm{A}$ は衝撃試験装置の搭載板, 分系 $\mathrm{B}$ は供試体に相 当し, 分系 $\mathrm{A}$ と分系 $\mathrm{B}$ は領域 $\mathrm{C}$ で結合されている. 結合自由度は $n$ とする. 分系 $\mathrm{A}$ の点 $\mathrm{f}$ を加振点, 点 $\mathrm{r}$ を観測 点（衝撃応答スペクトルの評価点）とする. 分系 $\mathrm{A}$ に注目すると分系 $\mathrm{A}$ のインピーダンス $\left[Z_{0}^{A}\right]$ は特性行列（質量 行列 $\left[M^{A}\right]$, 減衰行列 $\left[C^{A}\right]$, 剛性行列 $\left.\left[K^{A}\right]\right)$ を用いて以下のように表される 


$$
\left[Z_{0}^{A}\right]=\left[K^{A}\right]+j \omega\left[C^{A}\right]-\omega^{2}\left[M^{A}\right]
$$

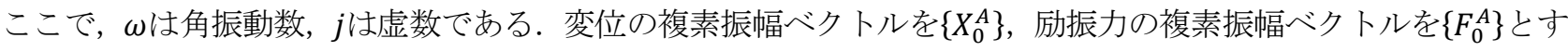
ると，分系 Aの運動方程式は以下のように記述できる.

$$
\left[Z_{0}^{A}\right]\left\{X_{0}^{A}\right\}=\left\{F_{0}^{A}\right\}
$$

結合領域 $\mathrm{C}$ に加振点 $\mathrm{f}$ ，観測点 $\mathrm{r}$ を加えた領域を $\mathrm{b}$ ，それ以外の領域を $\mathrm{a}$ とし，式(2)の変位ベクトル $\left\{X_{0}^{A}\right\}$ と励

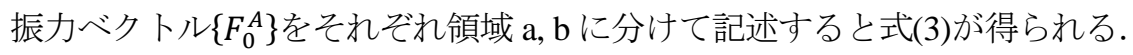

$$
\left[\begin{array}{cc}
Z_{a}^{A} & Z_{a b}^{A} \\
Z_{b a}^{A} & Z_{b}^{A}
\end{array}\right]\left\{\begin{array}{c}
X_{a}^{A} \\
X_{b}^{A}
\end{array}\right\}=\left\{\begin{array}{c}
0 \\
F_{b}^{A}
\end{array}\right\}
$$

ここで $\left\{X_{a}^{A}\right\},\left\{X_{b}^{A}\right\}$ は領域 $\mathrm{a}, \mathrm{b}$ における変位ベクトル, $\left\{F_{b}^{A}\right\}$ は領域 $\mathrm{b}$ の励振力ベクトルである. 式(3)を展開すると 式(4)が得られ，領域 $\mathrm{b}$ のみの変位と力の関係に縮小できる.

$$
\left[Z^{A}\right]\left\{X_{b}^{A}\right\}=\left\{F_{b}^{A}\right\}
$$

ただし，

$$
\left[Z^{A}\right]=Z_{b}^{A}-Z_{b a}^{A} Z_{a}^{A^{-1}} Z_{a b}^{A}
$$

であり, 式(5)で定義される $\left[Z^{A}\right]$ を縮小インピーダンスと呼ぶ. 領域 $\mathrm{b}$ を結合部 $\mathrm{c}$ とそれ以外の領域 $\mathrm{d}$ (加振点 $\mathrm{f}$ と観測点 $\mathrm{r}$ を含む領域）に分けると，式(4)は式(6)のように表すことができる.

$$
\left[\begin{array}{cc}
Z_{c}^{A} & Z_{c d}^{A} \\
Z_{d c}^{A} & Z_{d}^{A}
\end{array}\right]\left\{\begin{array}{c}
X_{c}^{A} \\
X_{d}^{A}
\end{array}\right\}=\left\{\begin{array}{c}
F_{c}^{A} \\
F_{d}^{A}
\end{array}\right\}
$$

次に, 分系 B の運動方程式について考えると, 分系 B は加振点と観測点を含まないことから結合部 $\mathrm{c}$ の変位と 力の関係から式(7)のようになる.

$$
\left[Z_{c}^{B}\right]\left\{X_{c}^{B}\right\}=\left\{F_{c}^{B}\right\}
$$

ここで, 結合部 $\mathrm{c}$ において, 分系 $\mathrm{A}$ と分系 $\mathrm{B}$ の変位は等しく, 働く力は作用反作用の関係にあることから次の関 係が成り立ち

$$
\left\{X_{c}^{A}\right\}=\left\{X_{c}^{B}\right\} \quad, \quad\left\{F_{c}^{A}\right\}=-\left\{F_{c}^{B}\right\}
$$

これを用いて式(6)と式(7)を結合すると式(9)が得られる.

$$
\left[Z^{A B}\right]\left\{X^{A B}\right\}=\left\{F^{A B}\right\}
$$

ここで

$$
\left[Z^{A B}\right]=\left[\begin{array}{cc}
Z_{c}^{A}+Z_{c}^{B} & Z_{c d}^{A} \\
Z_{d c}^{A} & Z_{d}^{A}
\end{array}\right] \quad, \quad\left\{X^{A B}\right\}=\left\{\begin{array}{c}
X_{c}^{A} \\
X_{d}^{A}
\end{array}\right\} \quad, \quad\left\{F^{A B}\right\}=\left\{\begin{array}{c}
0 \\
F_{d}^{A}
\end{array}\right\}
$$


である.これより，変位の振幅ベクトル $\left\{X^{A B}\right\}$ は以下の式で求められる.

$$
\left\{X^{A B}\right\}=\left[Z^{A B}\right]^{-1}\left\{F^{A B}\right\}
$$

$\left\{X^{A B}\right\}$ は変位の複素振幅ベクトルであることから, 加速度の複素振幅ベクトル $\left\{A^{A B}\right\}$ は以下の式で求められる.

$$
\left\{A^{A B}\right\}=-\omega^{2}\left\{X^{A B}\right\}
$$

この結果を用いて逆フーリエ変換を行えば加速度の時刻歴波形が計算でき，その結果を基に衝撃応答スペクトル が求められる．本研究では，Smallwoodの方法（Smallwood，1981）を用いて衝撃応答スペクトルを計算した，Q 值は 10 とした. なお，搭載板と供試体の間に調整機構を挿入する場合は 3 分系の構造モデルとなるが，この場合 もそれぞれの分系で縮小インピーダンスを求め, 同様の手順で計算すれば衝撃応答スペクトルを求めることがで きる.

しかし, 上述の方法では式(5)の縮小インピーダンス $\left[Z^{A}\right]$ を求める過程で分系 $\mathrm{A}$ の全自由度とほぼ同じ自由度を 持つ $Z_{a}^{A}$ の逆行列を計算する必要があり, この計算を広周波数帯域で行うと計算負荷が増大する. 特に, 今回タ一 ゲットとする衝撃応答スペクトルは 100 5,000Hz の周波数数帯域であり，上述した方法をそのまま適用するには 計算コストの低減が課題となる.

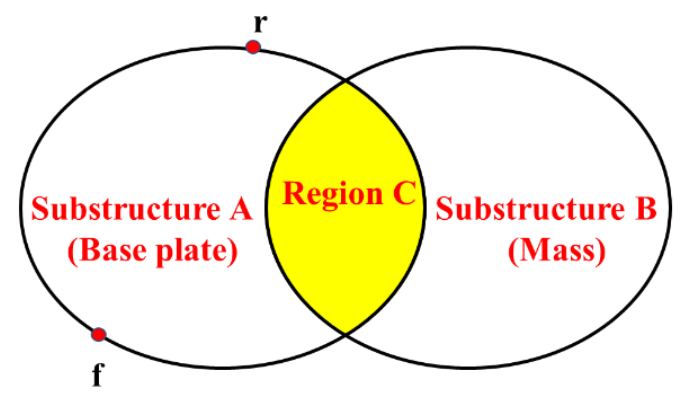

Fig. 2 Structure model including two substructures. The substructure A and B correspond to the base plate and the test specimen (Mass), respectively. They are connected in Region C. An external load is applied to the point $\mathrm{f}$ in the substructure A. The vibration response of the substructure $\mathrm{A}$ is measured at point $\mathrm{r}$.

\section{$2 \cdot 2$ 近似計算法の提案}

図 3 に衝撃試験で取得した加速度波形のパワースペクトルと衝撃応答スペクトルを示す. 図 3(a) と(b)の結果(図 中の Test Results）を比較してみると，衝撃応答スペクトルの波形はパワースペクトルのように周波数に応じて過 敏に変動せず，ピークとなるいくつかの振幅值（図 3(b)の赤丸）を結ぶように緩やかに変動していることがわか る. また，この赤丸で示した 2 つのピーク值は加速度パワースペクトルのピーク值（図 3(a)の赤丸） と概ね一致

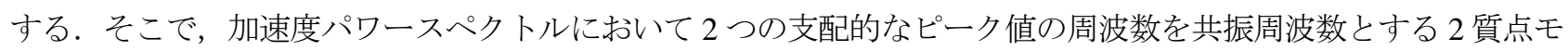
デルを作成し，このモデルに衝撃負荷を与えた際の衝撃応答スペクトルを計算した。その結果を図 3(b)の 2 Mass-model に示す. 図より, 2 質点モデルで求めた衝撃応答スペクトルは, 2 質点モデルの減衰等のパラメータ の影響により 2 つピーク值が元の衝撃応答スペクトルと若干シフトするものの, 実際の衝撃応答スペクトルの 概形を概ね再現できていることがわかる，これは，衝撃加速度の支配的な振動成分のみに着目寸れば衝撃応答ス ペクトルを近似的に予測できることを示唆する結果である. 


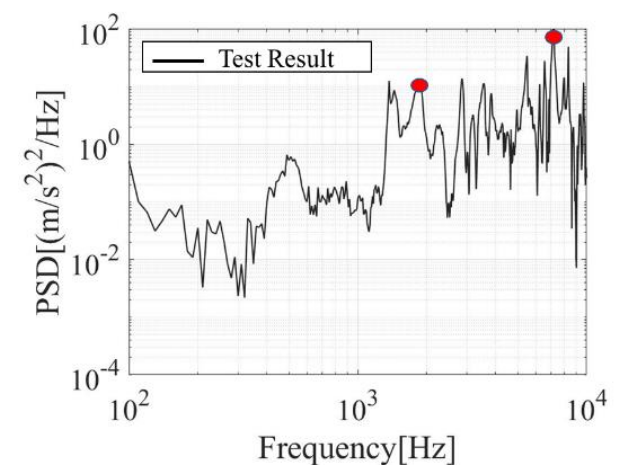

(a) Power spectrum density

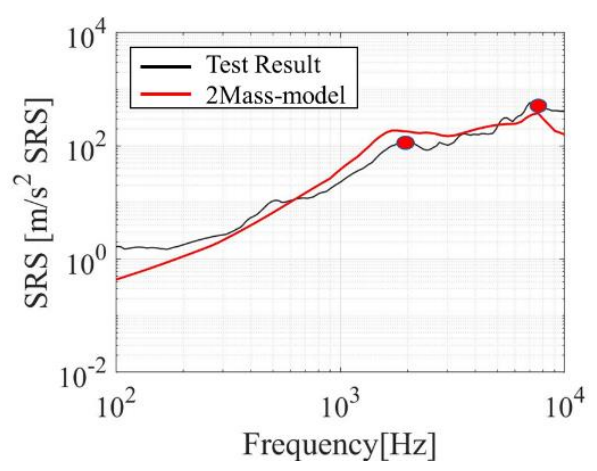

(b) Shock response spectrum

Fig. 3 Relation of power spectrum density and shock response spectrum. (a) Power spectrum density of the shock acceleration response measured in the shock test. (b) Shock response spectrum calculated from the same shock acceleration response. The red circles indicate predominant vibration components visually selected from the figures. The frequencies of the predominant vibration components are roughly the same in the figures (a) and (b). The red curve in the figure (b) represents the result given by two mass model whose resonance frequencies are set at the predominant frequencies marked with red circles. The prediction results given by two mass model are in rough agreement with the actual shock response spectrum.

そこで本研究では，衝撃加速度の支配的な振動成分のみを用いて縮小インピーダンスを求めることで，計算負 荷を低減しながら衝撃応答スペクトルを近似的に求める計算法を提案する. 衝撃加速度の支配的な振動成分は, 各分系（搭載板，調整機構，供試体）に対して刺激係数を求め, 刺激係数の大きい周波数（入力荷重の影響度が 大きいモード周波数）の応答成分とした。構造体の刺激係数 $\gamma_{n}$ の絶対值は質量行列と固有值解析から求まる固有 モードを用いて以下の式で求められる.

$$
\gamma_{n}=\frac{\left\{\varphi_{n}\right\}^{T}[M]\left\{\begin{array}{c}
1 \\
\vdots \\
1
\end{array}\right)}{\left\{\varphi_{n}\right\}^{T}[M]\left\{\varphi_{n}\right\}}
$$

ここに, $\left\{\varphi_{n}\right\}$ は $n$ 次の固有モードである.この刺激係数はモード周波数の数だけ計算されるため, 最大の刺激係 数に対して $1 \%$ 以上大きさの刺激係数を選定し, そのモード周波数を支配的な振動成分として設定した. ただ し，隣接するモード周波数を削減するためオクターブバンドで分割した周波数領域毎に最大となる刺激係数のみ を選定する. 図 4 に支配的な振動成分の具体的な選定方法を示す. 図の縦軸は刺激係数の絶対值, 横軸は周波数 である. 図中の縦線は周波数を 1/6 オクターブバンド毎に区切った線を示しており青丸は刺激係数である.罒の 例では刺激係数の最大值が 220 であることから，刺激係数の值が 2.2 以上のものを抽出する．抽出された刺激係 数が $1 / 6$ オクターブバンド内で複数存在する場合には最大のものだけを残し，残された刺激係数の周波数を支配 的な振動成分とする.

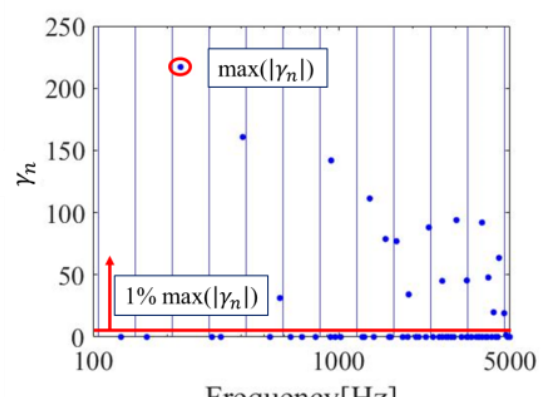

Frequency[Hz]

Fig. 4 Selection procedure of predominant vibration component. Ordinate represents the absolute value of the participation factor, and abscissa indicates the frequency. The frequency of the participation factor larger than $1 \%$ of the maximum value is selected as the frequency of the predominant vibration components. 
以上の計算を各分系に対して行い選定された支配的な振動成分だけを用いて各分系の縮小インピーダンスを計 算する．そして，これらを結合することで対象とする観測点の加速度スペクトルを計算する．この時求まる加速 度スペクトルは主要な振動成分のみに着目していることから不等間隔でサンプリングされた周波数応答関数とな っている. そこで，線形内挿補完を用いて等間隔にリサンプリングし，その結果を逆フーリエ変換することで加 速度時刻歴波形を求めた。 そして, Smallwood の方法（Smallwood, 1981）を用いて衝撃応答スペクトルを計算し た.

\section{3. 提案する近似計算法の有用性の検証}

\section{$3 \cdot 1$ 検証モデル}

図 5 に検証モデルを示す．図は筆者らが開発を行っている落鍾式衝撃試験装置（柳瀬他，2019）を想定した簡 易モデルである．図(a)は衝撃試験装置である搭載板（Base plate）に供試体（Mass）を取り付けたモデルであり， これを解析モデル 1 とする. 図(b)は搭載板と供試体の間に調整機構（Adjust structure）を取り付けたモデルであ り，これを解析モデル 2 とする. 解析モデル 1 では搭載板が分系 $\mathrm{A}$ に相当し, 供試体が分系 $\mathrm{B}$ となる. 一方, 解 析モデル 2 では搭載板が分系 $\mathrm{A}$, 供試体が分系 $\mathrm{B}$, 調整機構が分系 $\mathrm{C}$ の 3 分系となる. 図 1 に示寸落鍾式衝撃試 験装置では供試体と搭載板はボルトで数か所固定されていることから搭載板, 調整機構, 供試体の結合点をそれ ぞれ 4 点とし，4 本脚の単純構造で簡易的にモデル化した。

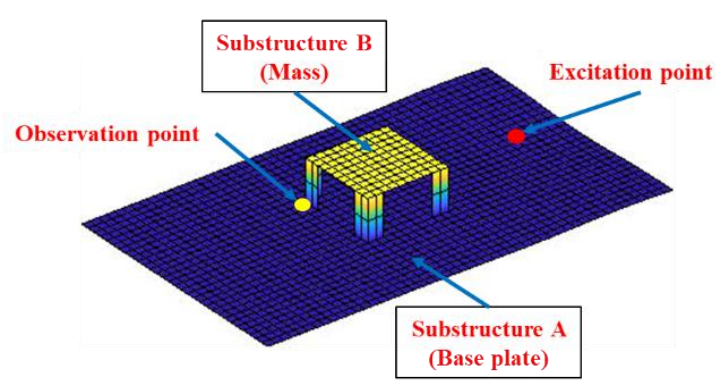

(a) 2substructure model (Analysis model 1)

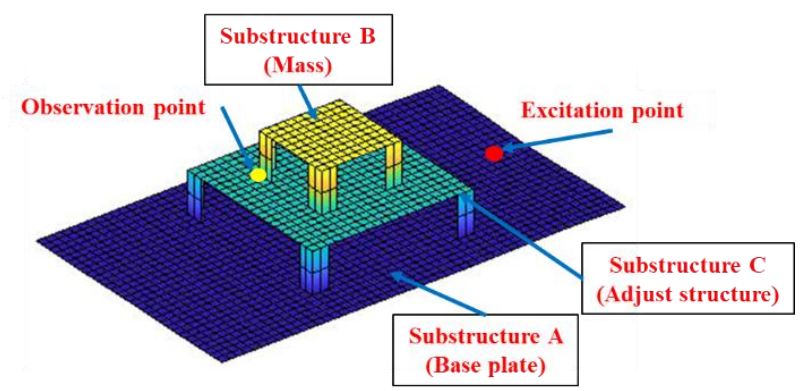

(b) 3substructure model (Analysis model 2)

Fig. 5 Test model. (a) Two-substructure model intended for the traditional drop-weight test device. (b) Three-substructure model intended for the developed drop-weight test device. These models are constructed using a four-node isoparametric shell element. The excitation point is installed on the base plate, and the observation point is set at the connection point of the substructures.

簡易モデルの構造数学モデルは有限要素モデルで作成し全て 4 節点シェル要素を用いた. 材質はアルミニウム とし，搭載板の境界条件は 4 隅を固定とした。座標系は搭載板中央を原点とし，搭載板の長手方向を $x$ 軸，面外 方向を $z$ 軸とした. 加振点は搭載板上の $x=0.25 \mathrm{~m}, y=0 \mathrm{~m}, z=0 \mathrm{~m}$ の位置とし (図中の Excitation point), 式(2)にお ける励振力の振幅ベクトル $\left\{F_{b}^{A}\right\}$ は 1 となるように設定した. 観測点（図中の Observation point）は供試体の結合点 のうち加振点から遠い位置とした．節点の自由度は $z$ 軸方向の並進成分 $\left(\boldsymbol{T}_{\boldsymbol{z}}\right), x$ 軸まわりの回転成分 $\left(\boldsymbol{R}_{\boldsymbol{x}}\right), y$ 軸まわりの回転成分 $\left(\boldsymbol{R}_{\boldsymbol{y}}\right)$ とした. 自由度からすると板曲げ要素と同じであるが，各自由度の影響調査や面内方 向に衝撃負荷を与える場合等への拡張性を考慮し，本研究ではシェル要素を利用した。各分系の質量行列と岡性 行列は汎用有限要素解析ソフトウェア FEAP（Zienkiewicz et al., 2005）を用いて作成し，減衰行列は以下の式によ り Reyleigh 減衰として与えた.

$$
[C]=\alpha[M]+\beta[K]
$$

$\alpha$ と $\beta$ は， $\alpha=11.4 ， \beta=2.9 \mathrm{e}-6$ とし $100 \mathrm{~Hz}$ と $1,000 \mathrm{~Hz}$ で $1 \%$ の減衰になるように設定した. そして，高い周波数 帯域のスペクトルを過度な減衰で抑え込まないようにした。縮小インピーダンス法による衝撃応答スペクトルの 
計算は Matlab® R2020a で行い，周波数範囲は $100 \mathrm{~Hz}$ 25,000Hz とした. 従来の縮小インピーダンス法による計 算では，周波数刻み幅を $10 \mathrm{~Hz}$ とした．表 1 に簡易モデルの詳細を示す.

Table 1 Parameters of analysis model.

\begin{tabular}{cccc}
\hline Parameter & Substructure A & Substructure B & Substructure C \\
\hline \hline Size $(\mathbf{W} \times \mathbf{H} \times \mathbf{T})[\mathbf{m m}]$ & $500 \times 300 \times 5$ & $100 \times 100 \times 50$ & $200 \times 200 \times 50$ \\
& & Plate $: 100 \times 100 \times 5$ & Plate $: 200 \times 200 \times 5$ \\
Legs $: 25 \times 25 \times 50(\mathrm{t}=5)$ & Legs : $25 \times 25 \times 50(\mathrm{t}=5)$ \\
\hline Young's modulus [MPa] & $7.0 \mathrm{E}+10$ & $7.0 \mathrm{E}+10$ & $7.0 \mathrm{E}+10$ \\
\hline Poisson ration [ - ] & 0.3 & 0.3 & 0.3 \\
\hline Density [kg/m $\left.\mathbf{m}^{\mathbf{3}}\right]$ & 2700 & 2700 & 2700 \\
\hline Number of mesh elements & 1500 & 132 & 432 \\
\hline Number of DOF & 4731 & 483 & 1443
\end{tabular}

\section{$3 \cdot 2$ 解析モデル 1 の検証結果}

図 6 に観測点の加速度パワースペクトルと加速度時刻歴波形を示す. 図は従来の縮小インピーダンス法 (RIM) と提案する近似計算法（Proposed method）を比較した結果である. 近似計算法で用いる振動成分は $1 / 6$ オクター ブバンド毎に抽出した。図 6(a)より，近似計算法で求めた加速度パワースペクトルは従来の縮小インピーダンス 法で求めた結果を平滑化したような結果となっている。これは，提案する近似計算法が支配的な振動成分のみを 用いて加速度スペクトルを計算し，その後線形内挿補完によりリサンプリングしなおすためである。近似計算法 の結果が加速度スペクトルのピーク值を完全に捉えていない理由は後に詳しく考察する. 図 6(b)の加速度時刻歴 波形をみると近似計算法で計算した結果は細かな応答を捉えきれていないものの支配的な応答が生じる位置をよ く表している. 初期状態で加速度が生じているのは加速度スペクトルの主要な振動成分以外を線形内挿補完して いるためであり，実際の加速度波形から求まるスペクトルとは異なるためである．図７に衝撃応答スペクトルを 比較した結果を示す. 図中の破線は従来の縮小インピーダンス法の結果を基準として NASA の衝撃試験規格

（NASA，2011）に定める $\pm 6 \mathrm{~dB}$ の試験公差範囲を示している. 図より，近似計算法で求めた衝撃応答スペクト ルは周波数に対して単調増加する傾向を示し, 衝撃応答スペクトルの局所的なピーク值を捉えられていない. し かし，その結果は土6dB の試験公差範囲には収まっており衝撃応答スペクトルの概略を近似的に予測できている ことがわかる.

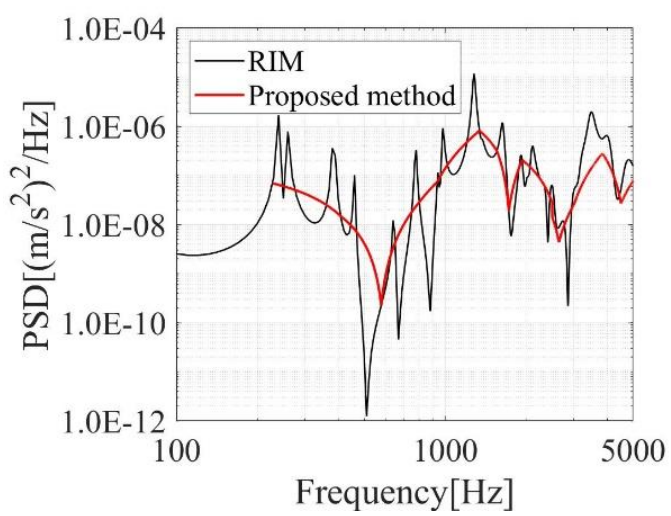

(a) Power spectrum density

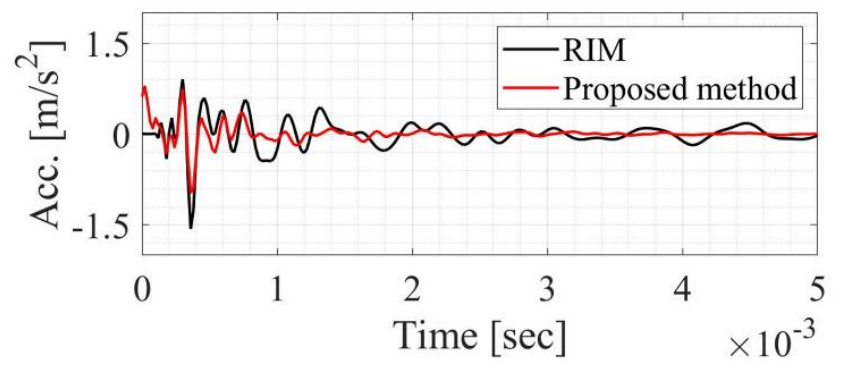

(b) Time history

Fig. 6 Analysis result on observation point. (a) Comparison on power spectrum density given by the traditional impedance method and the proposed method. (b) Comparison on acceleration time history. The proposed method roughly captures the predominant vibration responses at the observation point. 


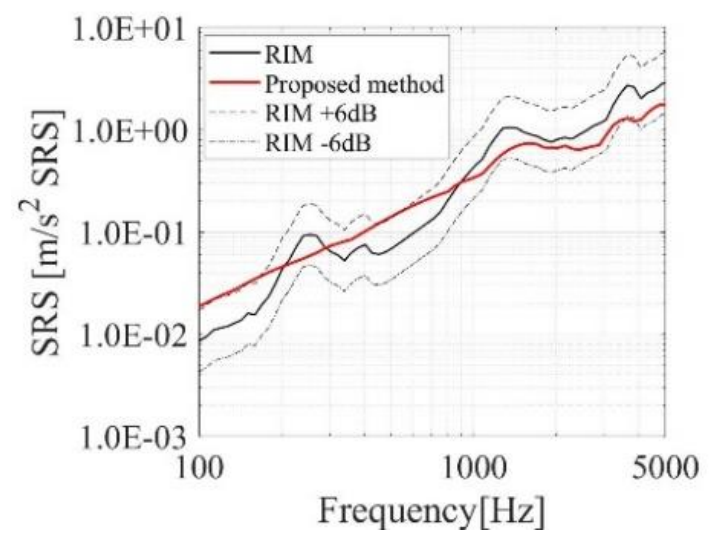

Fig. 7 Comparison on shock response spectrum. The proposed method cannot capture the localized spectrum variation, whereas it provides the overall trend of the shock response spectrum. The prediction accuracy of the proposed method is within $\pm 6 \mathrm{~dB}$ for the target spectrum in the treated model.

次に，提案する計算法が加速度パワースペクトルや衝撃応答スペクトルの局所的なピーク值を適切に捉えきれ ない理由について考察する. 図 8 に搭載板（分系 A）の特性行列を基に計算した刺激係数を示す. 横軸は周波数， 縦軸は刺激係数の絶対值である. 図 $8(\mathrm{a})$ は特性行列から求めた全刺激係数の分布であり, この結果を並進成分 $\left(T_{z}\right)$ と回転成分 $\left(R_{x}, R_{y}\right)$ に分けて表示した結果が図 8(b), (c)である. 図(b), (c)より，並進成分の刺激係数は回転成 分の刺激係数と比較すると 100 倍以上の值をとり，図 8(a)の全刺激係数から支配的な振動成分を抽出すると並進 成分が選定されることになる。すなわち，結合計算において回転成分の効果は考慮されない，そこで，回転成分 の効果を取り入れるため，並進成分（図 8(b)）と回転成分（図 8(c)）それぞれの刺激係数に対し最大值の $1 \%$ 以上 の值を支配的な振動成分として抽出し解析を行った.

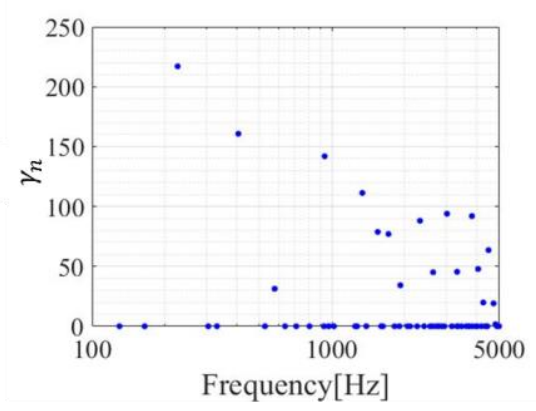

(a) $3 \mathrm{DOF}\left(T_{z}, R_{x}, R_{y}\right)$

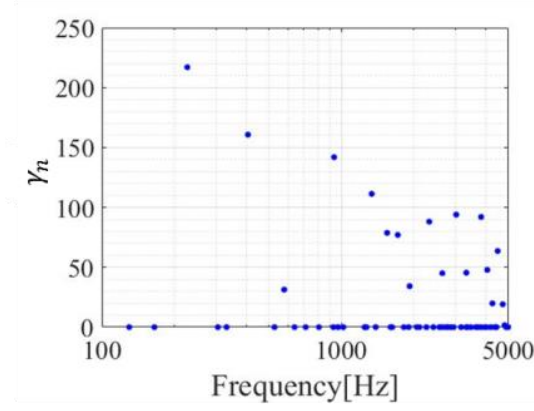

(b) 1DOF $\left(T_{z}\right)$

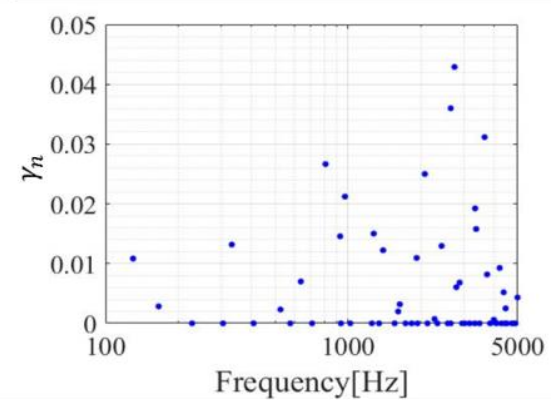

(a) $2 \mathrm{DOF}\left(R_{x}, R_{y}\right)$

Fig. 8 Participation factor in base plate (substructure A). (a) Participation factor on three degree of freedom. (b) and (c) indicate the breakdown of the participation factor in the figure (a). The participation factor on the three degree of freedom is almost the same in that on the translation degree of freedom, which implies that the participation factor on the rotational degree of freedom is not selected as the predominant components in the proposed method.

図 9 に解析結果を示す. 図 9(a)は観測点の加速度パワースペクトル, 図 9(b)は衝撃応答スペクトルである. 図 9(a)より回転成分を考慮すると提案する計算法の結果は加速度パワースペクトルの局所的なピーク值（図中○印） を精度よく捉えていることがわかる．全てのピーク值を完全に捉えきれていないのは解析で用いる振動成分の個 数が限定されているためである。また，図 9(b)の衝撃応答スペクトルの結果をみると，提案する計算法は回転成 分を考慮することによって $1,000 \mathrm{~Hz}$ 付近に局所的なピークが現れ従来の縮小インピーダンス法の結果と類似した 傾向を示している．衝撃応答スペクトルの振幅值が従来の縮小インピーダンス法の結果と比べて大きめの結果と なっているのは，提案する計算法が線形内挿補間を用いて支配的な振動成分以外の值を計算しているため，本来 
Fukuda, Yanagase and Iwasa, Transactions of the JSME (in Japanese), Vol.87, No.896 (2021)

生じる加速度スペクトルの谷を正しく見積もることができないためである（図 9(a)）。その結果，スペクトルの谷 の部分では加速度スペクトルが過大なり, 衝撃応答スペクトルは従来の縮小インピーダンス法の結果と比べて大 きくなっている.

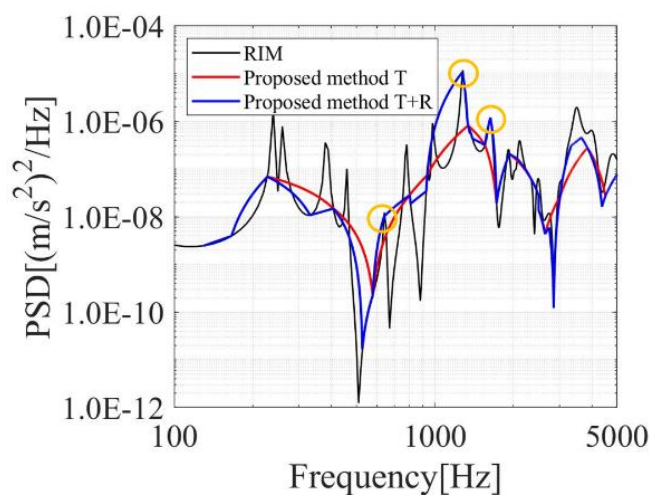

(a) Power spectrum density

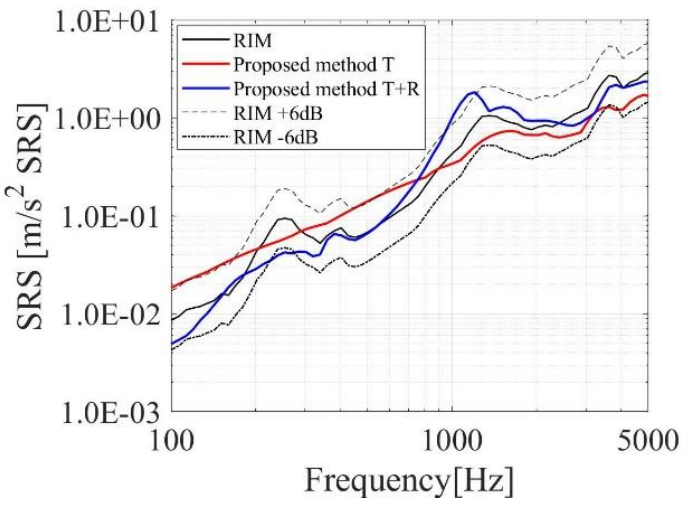

(b) Shock response spectrum

Fig. 9 Comparison on power spectrum density and shock response spectrum. The proposed method simulates the localized spectrum variation by analyzing the effects of the rotational components.

次に, 提案する計算法の予測精度と支配的な振動成分の数について考察する. 図 10 に加速度パワースペクトル と衝撃応答スペクトルの結果を示す. 同図は，提案する近似計算法において支配的な振動成分を選択する周波数 範囲を $1 / 6 ， 1 / 3 ， 1 / 2 ， 1$ オクターブバンドと変化させた結果を比較したものである. オクターブバンドの数值が 大きくなるほど解析で用いる振動成分の数は少なくなる. 図より，1/6 から 1 オクターブバンドまで周波数範囲 を広くしていくと衝撃応答スペクトルの結果は従来の縮小インピーダンス法の結果から離れていき， 1 オクター ブバンドの結果では $\pm 6 \mathrm{~dB}$ の試験公差範囲を大きく逸脱する箇所が現れる.この試験公差範囲を基準とすると $1 / 6$ オクターブバンドと $1 / 3$ オクターブバンドの結果に大きな差がなく両者ともに公差範囲内に収まっている. その ため, 今回の検証モデルでは $1 / 3$ オクターブバンドの結果が予測精度と計算負荷の双方の視点から最適な結果で あることがわかる．表 2 に提案する計算法で用いた支配的な振動成分の数と解析時間について纒める. 表に示す ように，提案する近似計算法で用いる振動成分の数は $1 / 3$ オクターブバンドの場合で従来の縮小インピーダンス 法の $1 / 86$ 程度となり，これに比例して解析時間も小さくなっている. 以上より，今回提案した計算法は計算負荷 を抑えつつ衝撃応答スペクトルを近似的に予測するのに有用な方法であることがわかる.

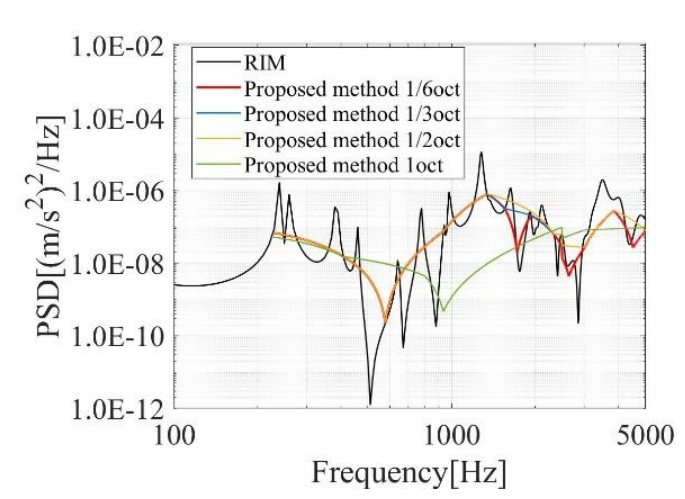

(a) Power spectrum density

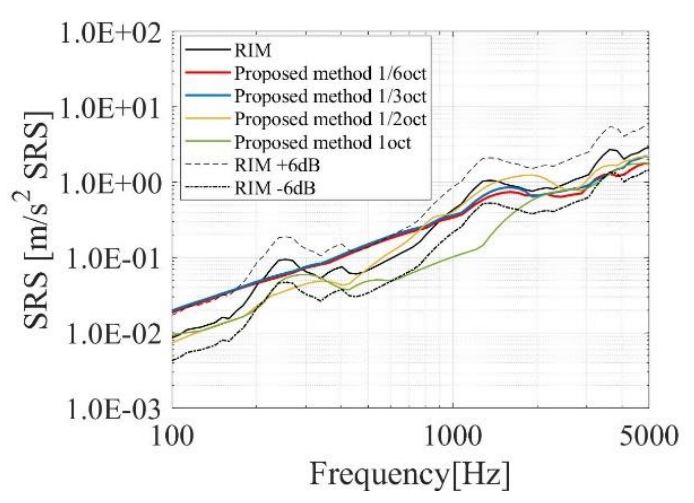

(b) Shock response spectrum

Fig. 10 Relation of computation accuracy and number of participation factors. The computation accuracy is reduced as the number of the participation factor decreases. Specially, the computation accuracy is significantly reduced in the treated model when the octave-band width is larger than $1 / 2$. 
Fukuda, Yanagase and Iwasa, Transactions of the JSME (in Japanese), Vol.87, No.896 (2021)

Table 2 Number of selected mode frequencies and calculation time for each case.

\begin{tabular}{|c|c|c|c|c|c|}
\hline & RIM & 1/6oct & 1/3oct & 1/2oct & loct \\
\hline Number of mode frequencies & 2501 & 39 & 29 & 22 & 16 \\
\hline Calculation Time(min) & 5678 & 96 & 71 & 48 & 42 \\
\hline
\end{tabular}

\section{$3 \cdot 3$ 解析モデル 2}

次に，提案する近似計算法を用いて搭載板，調整機構，供試体の 3 分系からなる検証モデルを解析した結果を 示す. 図 11 は観測点の加速度パワースペクトルと加速度時刻歴波形を示す. 近似計算法では $1 / 6$ オクターブバン ド毎に支配的な振動成分を抽出した。図より，前節の 2 分系モデルと同様に近似計算法で求めた加速度スペクト ルは従来の縮小インピーダンス法の結果を平滑化したような結果となっている．また，加速度時刻歴波形は支配 的な振動を概ね再現できていることがわかる.図 12 は衝撃応答スペクトルを比較した結果であるが近似計算法で 求めた結果は従来の縮小インピーダンス法の結果を $\pm 6 \mathrm{~dB}$ の試験公差範囲内で計算できている.

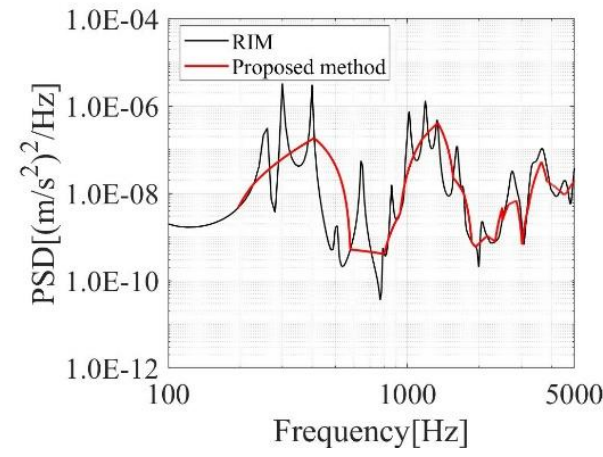

(a) Power spectrum density

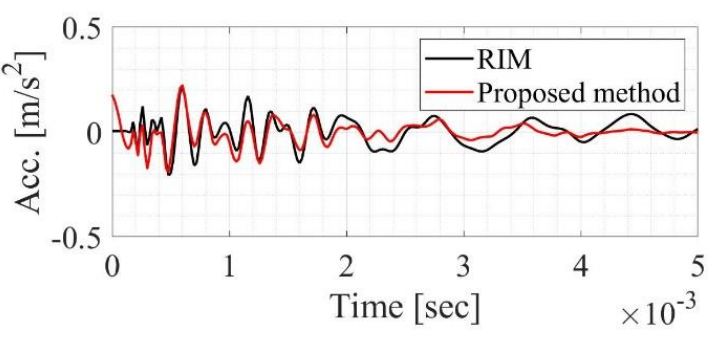

(b) Time history

Fig. 11 Acceleration on observation point. (a) Comparison on power spectrum density given by the traditional impedance method and the proposed method. (b) Comparison on acceleration time history. The proposed method roughly captures the predominant vibration responses at the observation point even when the number of the substructure increases.

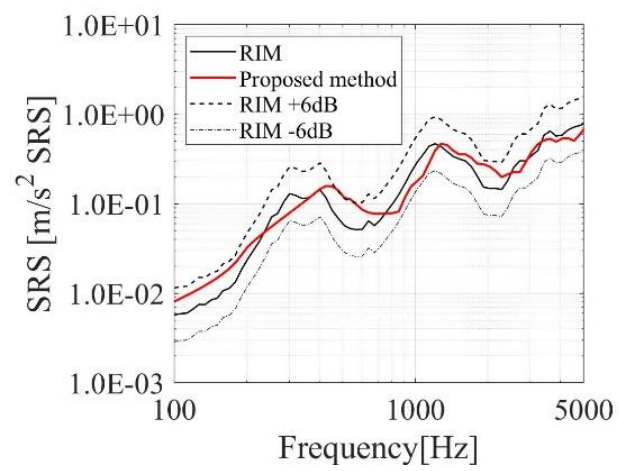

Fig. 12 Comparison on shock response spectrum. The proposed method can compute the shock response spectrum within accuracy of $\pm 6 \mathrm{~dB}$.

図 13 に近似計算法で用いる支配的な振動成分の数を変えて計算した結果を示す. 図は，2分系の場合と同様に 刺激係数を選択する周波数範囲を $1 / 6,1 / 3 ， 1 / 2 ， 1$ オクターブバンドと変化させた結果である. 図より，1 オク ターブバンドの結果は $\pm 6 \mathrm{~dB}$ の試験公差範囲を冕脱する箇所があるが， 2 分系の場合と同様に $1 / 6$ オクターブバン ドの結果と $1 / 3$ オクターブバンドは同じような結果となり試験公差範囲内に収まっている. そのため，3 分系モ 
デルにおいても $1 / 3$ オクターブバンドの結果が予測精度と計算負荷の視点から最適な結果となっている. 表 3 に 近似計算法で用いた支配的な振動成分の数と解析時間を䌕めた結果を示寸. 表より, 近似計算法で用いる振動成 分の数は $1 / 3$ オクターブバンドの場合で従来の縮小インピーダンス法の約 $1 / 60$ となり, 解析時間も同定に低減さ れている．これにより，調整機構を加えた 3 分系モデルにおいても今回提案した近似計算法は計算負荷を抑えつ つ衝撃応答スペクトルを近似的に予測するのに有用な方法であることがわかる.

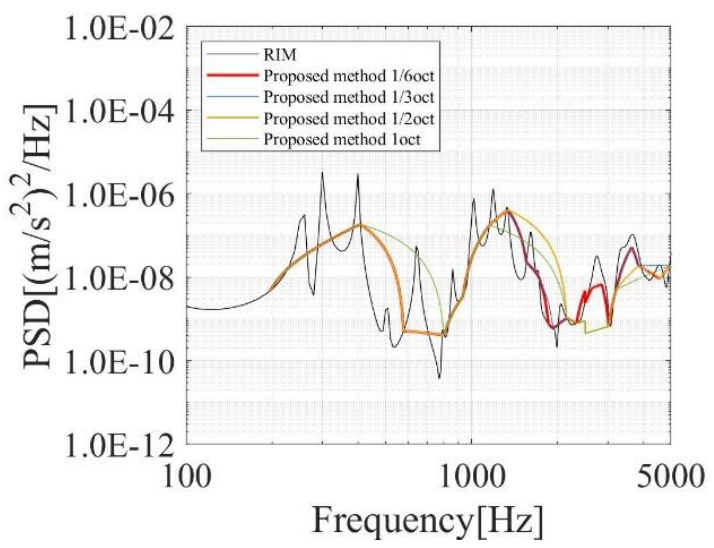

(a) Power spectrum density

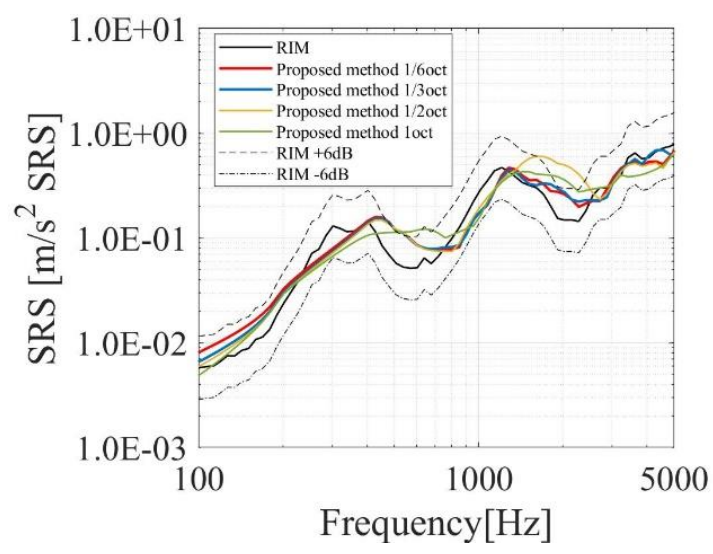

(b) Shock response spectrum

Fig. 13 Relation of computation accuracy and number of participation factors. Similar to the results of two-substructure model in Fig. 10, the computation accuracy is reduced as the number of the participation factor decreases. Specially, the computation accuracy is significantly reduced in the treated model when the octave-band width is larger than $1 / 2$.

Table 3 Comparison on number of selected vibration component and computation time.

\begin{tabular}{|c|c|c|c|c|c|}
\hline & RIM & 1/6oct & 1/3oct & 1/2oct & 1oct \\
\hline Number of mode frequencies & 2501 & 62 & 43 & 33 & 24 \\
\hline Calculation Time(min) & 7611 & 187 & 145 & 99 & 78 \\
\hline
\end{tabular}

以上， $\pm 6 \mathrm{~dB}$ の公差を精度の目標值とした場合において，2つのモデルを対象に提案した近似計算法の有効性 について示した。本ケースでは公差を満足する結果が得られたが，他のケースでは公差を逸脱してしまう可能性 がある.しかしながら土6 dB の範囲を多少超える場合についても, 実試験において発生する数倍〜十倍程度の才 ーバーテストを回避できるため，今回得られた結果は実用上の意義があると考えられる．提案した計算法は各分 系の支配的な振動応答を刺激係数により抽出し, オクターブバンド毎に 1 つの振動成分を割り当てる.その結果， 計算で用いる振動成分は広い周波数範囲にわたって概ね均等に配置され極端な偏りが生じない. 本論文で提案す る近似計算法が 2 つモデルで有効に機能した理由はこの点にあると考えており，提案する近似計算法の汎用性 がうかがえる.しかし，近似計算における最適なオクターブバンド幅は，検証に利用する基準值 (本論文では NASA の試験公差範囲を利用）に依存し，且つモデルにも依存すると考えられる．そのため，提案する近似計算法を実 試験へ利用するにあたっては予測精度を定量的に評価していくことが重要であり，今後は試験データとの比較を 行い提案する近似計算法の信頼性について詳細に検証していく予定である.

\section{4. 結 言}

本研究は，落錘式衝撃試験装置を対象に従来の縮小インピーダンス法の計算負荷を低減させつつ衝撃応答スペ クトルを近似的に求める計算法を提案した。提案した近似計算法は刺激係数を用いて各分系の支配的な振動成分 を抽出し，抽出した振動成分のみを利用して衝撃応答スペクトルを求める方法である. 提案した近似計算法の有 用性を落錘式衝撃試験装置の簡易モデルを対象に検証した結果，提案する近似計算法は衝撃応答スペクトルを 
NASA の衝撃試験規格（NASA, 2011）が定める $\pm 6 \mathrm{~dB}$ の試験公差範囲内で予測することができ，従来の縮小イン ピーダンス法の計算負荷を低減させつつ衝撃応答スペクトルの概略を簡易的に予測するのに有用な方法であるこ とを示した，今後は，提案手法を実試験へ適用し，予測結果と実測值との比較を通して予測誤差を定量的に評価 し，予測結果の信頼性を検証していく予定である.

\section{謝 辞}

本研究は, JSPS 科研費 $18 K 04570$ の助成を受けたものです.

\section{文献}

雨川洋章, 山田浩之, 立山耕平, 山㟝祥弘, 伊海田皓史, 紙田徹, 西元美希, ロケット衛星フェアリング分離機 構向けノッチ付ボルトの分離挙動評価，日本航空宇宙学会論文集，Vol. 67, No. 2 (2019), pp. 57-66.

畑村透, 増井博一, 趙孟佑, 前野一夫, 超小型衛星の衝撃試験レベル調整方法に関するシミュレーション, 日本 航空宇宙学会論文集，Vol. 63, No. 3 (2015), pp. 117-118.

宇宙航空研究開発機構, 衝撃試験ハンドブック, JERG-2-130-HB001, A 改訂版 (2017).

Lee, J., Chia, C. C. and Kong, C., Review of pyroshock wave measurement and simulation for space systems, Measurement, Vol. 45, No. 4 (2012), pp. 631-642.

長松昭男，大熊政明，部分構造合成法，培風館 (1991), pp. 91-93.

長松昭男, 大熊政明, 藤田豊, 池内盿隆, 白井正明, 縮小インピーダンス合成法による強制振動の解析 IV 多重 化の提案とディーゼル発電パッケージ台盤への適用，日本機械学会論文集 C 編，Vol. 48, No. 432 (1982), pp. 1129-1136.

National Aeronautics and Space Administration (NASA), Pyroshock test criteria, NASA-STD-7003, revision A (2011).

Smallwood, D. O., An improved recursive formula for calculating shock response spectra, Shock and Vibration Bulletin, No. 51 (1981), pp.211-217.

Wang, X., Qin, Z., Ding, J. and Chu, F., Finite element modeling and pyroshock response analysis of separation nuts, Aerospace Science and Technology, Vol. 68 (2017), pp. 380-390.

柳瀬恵一, 福田達輝, 岩佐貴史, 伝達関数合成法を用いた衝撃応答スペクトラムの予測における合成成分の選択, 日本機械学会論文集, Vol. 87, No. 894 (2021), DOI:10.1299/transjsme.20-00341.

Yanagase, K., Fukuda, T., Iwasa, T. and Obata, Y. Study on the tuning method of shock test condition for spacecraft instruments, Transactions of the Japan Society for Aeronautical and Space Sciences, Aerospace Technology Japan, Vol. 19, Issue 3 (2020), pp. 77-83.

柳瀬恵一, 福田達輝, 岸本拓也, 岩佐貴史, 小畑良洋, 宇宙機コンポーネント衝撃試験における衝撃応答スペクト ラムの事前予測手法の検討, 第 28 回スペース・エンジニアリング・コンファレンス講演論文集, No.19-344, $\mathrm{C} 02$ (2019).

Zienkiewicz, O. C., Taylor, R. L. and Zhu, J. Z., The finite element method set (Sixth edition), Oxford, Butterworth-Heinemann (2005).

\section{References}

Amakawa, H., Yamada, H., Tateyama, K., Yamasaki, Y., Ikaida, H., Kamita, T. and Nishimoto, M., Separation behavior evaluation of notched bolt for rocket payload fairing separation system, Transactions of Japan Society for Aeronautical and Space Science, Vol. 67, No. 2 (2019), pp. 57-66 (in Japanese).

Hatamura, T., Masui, H., Cho, M. and Maeno, K., The simulation about adjustment method of shock level of nano satellites, Transactions of Japan Society for Aeronautical and Space Science, Vol. 63, No. 3 (2015), pp. 117-118 (in Japanese).

Japan Aerospace Exploration Agency, Shock test handbook, JERG-2-130-HB001, revision A (2017), p.32 (in Japanese).

Lee, J., Chia, C. C. and Kong, C., Review of pyroshock wave measurement and simulation for space systems, Measurement, Vol. 45, No. 4 (2012), pp. 631-642.

Nagamatsu, A. and Okuma, M., Component mode synthesis, baifukan (1991), pp.91-93 (in Japanese).

Nagamatsu, A., Okuma, M., Fujita, Y., Ikeuchi, T. and Shirai, M., Analysis of vibration by reduction impedance method (part.4 Proposal for multiple method and application of diesel generator panel), Transactions of the Japan Society of 
Mechanical Engineers, Series C, Vol. 48, No. 432 (1982), pp. 1129-1136 (in Japanese).

National Aeronautics and Space Administration (NASA), Pyroshock test criteria, NASA-STD-7003, revision A (2011).

Smallwood, D. O., An improved recursive formula for calculating shock response spectra, Shock and Vibration Bulletin, No. 51 (1981), pp.211-217.

Wang, X., Qin, Z., Ding, J. and Chu, F., Finite element modeling and pyroshock response analysis of separation nuts, Aerospace Science and Technology, Vol. 68 (2017), pp. 380-390.

Yanagase, K., Fukuda, T. and Iwasa, T., Method for selecting axes for prediction of shock response spectrum using transfer function synthesis, Transactions of the JSME (in Japanese), Vol. 87, No. 894 (2021), DOI:10.1299/transjsme.20-00341.

Yanagase, K., Fukuda, T., Iwasa, T. and Obata, Y., Study on the tuning method of shock test condition for spacecraft instruments, Transactions of the Japan Society for Aeronautical and Space Sciences, Aerospace Technology Japan, Vol. 19, Issue 3 (2020), pp. 77-83.

Yanagase, K., Fukuda, T., Kishimoto, T., Iwasa, T. and Obata, Y., Prediction method of shock response spectrum in spacecraft component shock test, Proceedings of 28th JSME Space Engineering Conference, No.19-344, C02 (2019) (in Japanese).

Zienkiewicz, O. C., Taylor, R. L. and Zhu, J. Z., The finite element method set (Sixth edition), Oxford, Butterworth-Heinemann (2005). 